\title{
BMJ Open Adherence to UNRWA's anaemia treatment guidelines in the Jerash Camp Health Centre, Jordan: a retrospective observational study
}

\author{
Yuriko Harada (D) , ${ }^{1}$ Nada Abu Kishk, ${ }^{2}$ Shakoor Hajat, ${ }^{3}$ Mio Akita, ${ }^{2}$ \\ Masako Horino, ${ }^{2,4}$ Shatha Albaik, ${ }^{2}$ Khalil Abu Naqera, ${ }^{5}$ Majed Hababeh, ${ }^{2}$ \\ Rami Habash, ${ }^{2}$ Akihiro Seita ${ }^{2}$
}

To cite: Harada Y, Kishk NA, Hajat S, et al. Adherence to UNRWA's anaemia treatment guidelines in the Jerash Camp Health Centre, Jordan: a retrospective observational study. BMJ Open 2022;12:e056490. doi:10.1136/ bmjopen-2021-056490

- Prepublication history and additional supplemental material for this paper are available online. To view these files, please visit the journal online (http://dx.doi.org/10.1136/ bmjopen-2021-056490).

Received 17 August 2021 Accepted 04 February 2022

Check for updates

(C) Author(s) (or their employer(s)) 2022. Re-use permitted under CC BY-NC. No commercial re-use. See rights and permissions. Published by BMJ.

For numbered affiliations see end of article.

Correspondence to Yuriko Harada; yurikoharada22@gmail.com

\section{ABSTRACT}

Objective The United Nations Relief and Works Agency for Palestine Refugees in the Near East (UNRWA) provides primary healthcare to 2.2 million Palestinian refugees in Jordan. This study aimed to measure patient and doctor adherence to the UNRWA guidelines for the prevention and treatment of iron deficiency anaemia in moderate to severe anaemia children, defined as haemoglobin $(\mathrm{Hb})$ level $<10.0 \mathrm{~g} / \mathrm{L}$.

Design, setting and participants A retrospective observational study was conducted by analysing the electronic health records of 717 children ( 353 boys and 364 girls) children aged 12 months old in 2018 in the Jerash Camp Health Centre, Jordan.

Outcome Patient adherence to the UNRWA guidelines was calculated by the proportion of health centre visits and doctor adherence by the proportions of $\mathrm{Hb}$ tests and iron supplementation among moderate to severe anaemia children at screening, first, second and third follow-up visits, respectively using STATA.

Results The prevalence of moderate to severe anaemia was $15.6 \%$ among 12-month-old children. After 1 month of iron supplementation, $83.7 \%$ of anaemic children improved their Hb status: mean \pm SD from $9.1 \pm 0.6 \mathrm{~g} / \mathrm{L}$ to $10.1 \pm 1.0 \mathrm{~g} / \mathrm{L}$. Patient and doctor adherence to the UNRWA guidelines was above $80 \%$ at the screening visit but progressively decreased at follow-up visits, especially patient adherence at the third follow-up visit of $34.4 \%$. The analysis revealed unnecessary health centre visits and iron supplementation being given to mildly anaemic children ( $\mathrm{Hb}$ level=10.0 g/L-10.9 g/L). Additionally, children visited the health centre at an age significantly later compared with that recommended by the UNRWA guidelines for the screening, first and second follow-up visits ( $p$-value $<0.05$ ). Conclusion Adherence to the UNRWA guidelines was above $80 \%$ at screening but much lower at follow-up visits. Urgent action is needed to improve adherence at follow-up visits and to minimise any unnecessary health centre visits and iron supplementation to mildly anaemic children.

\section{BACKGROUND}

Anaemia is caused by a decreased quantity of red blood cells, diminished haemoglobin
Strengths and limitations of this study

- This was the first study analysed the patient and doctor adherence to the United Nations Relief and Works Agency for Palestine Refugees in the Near East's (UNRWA) guideline on the prevention and treatment of childhood anaemia.

- We included all children aged 12 months old, registered in the Jerash Health Centre operated by the UNRWA.

- Potential confounding factors could not be analysed due to the lack of information in electronic health records.

level or altered morphology of red blood cells. ${ }^{1}$ It has been estimated that 2 billion people (25\% of the world's population) had anaemia globally in 2016, and developing countries accounted for more than $89 \%$ of the burden. ${ }^{23}$ The most common cause of anaemia is iron deficiency anaemia, affecting 1.2 billion ( $15 \%$ of the world population) ${ }^{12} \mathrm{It}$ happens when there are no mobilisable iron stores because of a prolonged negative iron balance, ${ }^{4}$ and young children and women are at high risk. ${ }^{3}$ High burden of anaemia and iron deficiency anaemia among children in Jordan were reported. In 2019, WHO estimated that prevalence of anaemia, defined as $\mathrm{Hb}$ level $<11.0 \mathrm{~g} / \mathrm{L}$, was $32.7 \%$ among children below 5 years old in Jordan. ${ }^{5}$ Additionally, a study conducted among children aged 12-23 months old in Jordan reported that prevalence of anaemia, defined as $\mathrm{Hb}$ level $<11.0 \mathrm{~g} / \mathrm{L}$, was $34.4 \%$ in $2002 .{ }^{6}$ This study further investigated that the prevalence of iron deficiency anaemia, defined as $\mathrm{Hb}$ level $<11.0 \mathrm{~g} / \mathrm{L}$ and serum ferritin level $<12.0$ $\mu \mathrm{g} / \mathrm{L}$, was $21.3 \%$ among children aged $12-23$ months old. ${ }^{6}$ There is evidence that children below 2 years old with iron deficiency 
anaemia are more susceptible to poorer cognitive, motor, social-emotional and neurophysiologic development. ${ }^{78}$ Additionally, children with iron deficiency anaemia have a higher risk of mortality and infectious diseases. ${ }^{9} 10$ Because anaemia caused by depletion of iron status may be irreversible in young children, ${ }^{4}$ it is crucial to prevent and treat iron deficiency anaemia as early as possible before it becomes severe or chronic to maintain normal growth and development. ${ }^{11} 12$

In Jordan, the United Nations Relief and Works Agency for Palestine Refugees in the Near East (UNRWA) provides services in 10 refugee camps for 2.2 million Palestinian refugees. ${ }^{13} 14$ UNRWA is the main primary healthcare provider for Palestinian refugees, and it provides health services free of charge ${ }^{13}$ In 2019, UNRWA reported a high burden of anaemia among Palestinian refugee children in Jordan; the overall prevalence of anaemia, defined as $\mathrm{Hb}$ level $<11.0 \mathrm{~g} / \mathrm{L}$, was $39 \%$ among 12 -month-old children, which could be attributed to continuous food insecurity, low iron intake and poor dietary habits. ${ }^{14} 15$

UNRWA provides guidelines for the prevention and treatment of iron deficiency anaemia for 12-month-old Palestinian refugee children, which consist of mandatory anaemia screening and subsequent treatment instructions ${ }^{4}$ based on recommendations by the WHO. ${ }^{16}$ According to UNRWA prevention and treatment guideline for micronutrient deficiency (UNRWA guidelines), all children registered in UNRWA health centres should complete anaemia screening at the age of 12 months. The UNRWA guidelines define the threshold for diagnosing childhood anaemia is $\mathrm{Hb}$ level $<11 \mathrm{~g} / \mathrm{L}$. The severity of childhood anaemia was classified with child $\mathrm{Hb}$ status as mild $(10.0 \mathrm{~g} / \mathrm{L}-10.9 \mathrm{~g} / \mathrm{L})$, moderate $(7.0 \mathrm{~g} / \mathrm{L}-9.9$ $\mathrm{g} / \mathrm{L})$ and severe $(<7.0 \mathrm{~g} / \mathrm{L})$ anaemia. If the child is diagnosed as moderate to severely anaemic, defined as a $\mathrm{Hb}$ level $<10 \mathrm{~g} / \mathrm{L}$, they receive iron treatment at a dose of 25 mg elemental iron every day for 3 months. During the 3 months of treatment, children need to have repeated $\mathrm{Hb}$ tests after 1 month at the age of 13 months old. If the $\mathrm{Hb}$ concentration improves compared with the $\mathrm{Hb}$ level at the screening visit, each child continues the iron supplementation for two more months until the age of 15 months, along with dietary counselling by trained nursing staff. Six months after completing the treatment, at the age of 21 months old, a reassessment of $\mathrm{Hb}$ level is recommended. By contrast, if the $\mathrm{Hb}$ concentration does not improve despite patient and doctor adherence with the iron treatment and the absence of any acute illness, further laboratory tests including Complete Blood Cell Count (CBC), Mean Corpuscular Volume (MCV), Mean Corpuscular Haemoglobin (MCH) and Red Cell Distribution (RDW) and/or referral to a specialist is recommended. ${ }^{4}$ The flowchart in online supplemental file 1 summarises the UNRWA guidelines and procedure for iron deficiency anaemia detection and treatment.

No previous study has been conducted to investigate adherence to the UNRWA guidelines in Jerash Palestinian refugee camp, which is the poorest camp in Jordan. ${ }^{17}$ The main aim of this study was to investigate adherence to the UNRWA guidelines among patients and doctors in the Jerash Camp Health Centre, Jordan.

\section{METHODS}

\section{Study design}

A retrospective observational study was conducted using data from electronic health records from the Jerash Camp Health Centre, operated by UNRWA, to measure patient and doctor adherence to the UNRWA guidelines.

\section{Study setting}

Jerash camp was establishedfor 11,500 Palestinian refugees as an emergency camp in Jordan for Palestinian refugees who fled from the Gaza Strip in 1968 as a consequence of the 1967 Arab-Israeli war. ${ }^{18}$ The camp covers an area of $0.75 \mathrm{~km}^{2} .{ }^{18}$ In 2013 , Jerash camp was reported to be the poorest among 10 Palestinian refugee camps in Jordan, with $52.7 \%$ of the population having incomes below the national poverty line of 814 Jordanian Dinars per capita per year. ${ }^{1718}$ Additionally, it was estimated that $88 \%$ of refugees in Jerash camp did not have health insurance for secondary or tertiary care by governorate, and $42 \%$ of the population were reported to experience catastrophic health expenditure. ${ }^{17-19}$

\section{Eligibility criteria and sampling}

The inclusion criteria were Palestinian refugee children who were aged 12 months old in 2018 (ie, born between 1 January and 31 December 2017) and registered in the Jerash Camp Health Centre. Our exclusion criteria were non-Palestinian refugee children born in Jerash. There were 800 children registered in the Jerash Camp Health Centre who were born in 2017, and all of them were included in the analysis. Because we included the whole study population who met the inclusion criteria in the analysis, we did not conduct a sample size calculation. By accessing the electronic health records from the Jerash Camp Health Centre, we collected seven categories of data for each child as shown in online supplemental file 2. At screening and the first, second and third follow-up visits, the following information was collected: the number of children who visited the health centre, age in months at health centre visits, the number of children who took the $\mathrm{Hb}$ test, their $\mathrm{Hb}$ levels and whether they were prescribed iron supplements. Finally, for the first, second and third follow-up visits, information on the number of children who took other laboratory tests was also collected. The sex of each child was also recorded from the electronic health records.

\section{Statistical analysis}

Relevant electronic health records were extracted from the main UNRWA database and imported into a statistical computing package. Data were summarised using mean and SD for the continuous variables of child age and child $\mathrm{Hb}$ level at each health centre visit. For 
Figure 1 Children's flow in Jerash Camp Health Centre

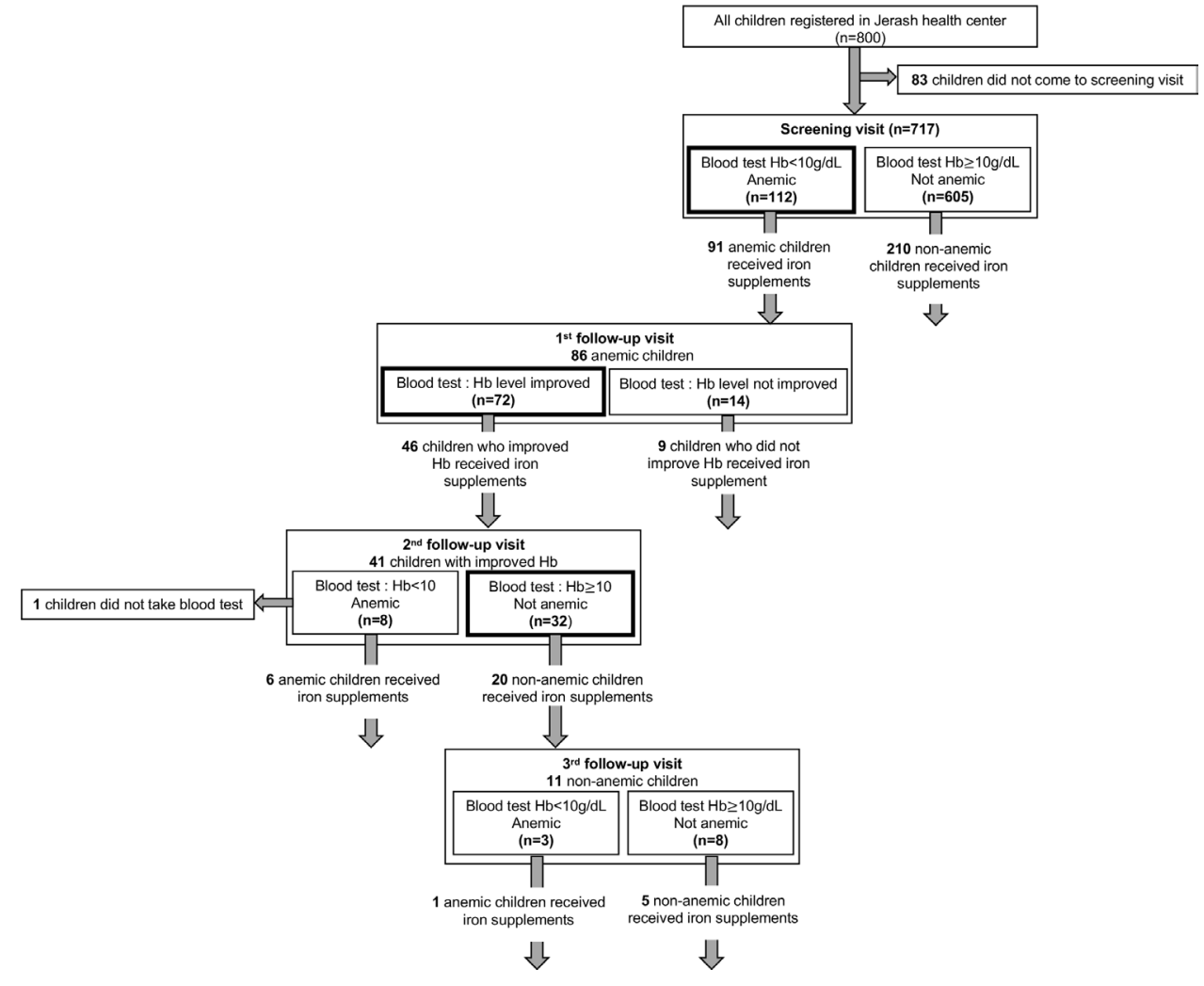

categorical variables, the frequencies and percentages of children who visited the health centre, received the $\mathrm{Hb}$ test, were diagnosed as anaemic, and received iron supplements were calculated. Additionally, for the first follow-up visit, the frequencies and percentages of children who improved their $\mathrm{Hb}$ status compared with the screening visit were calculated. One-sample t-tests were conducted to investigate whether the mean age at each health centre visit was significantly different from the age defined in the UNRWA guidelines, with resulting p-values deemed statistically significant at the $5 \%$ level. Based on UNRWA guidelines, ${ }^{4}$ patient adherence was calculated by the proportion of the health centre visits, and doctor adherence was calculated by the proportions of $\mathrm{Hb}$ tests and iron supplementation among moderate to severe anaemia children at screening, first, second and third follow-up visits, respectively. The definition of patient and doctor adherence is shown in online supplemental file 3 . STATA V.14 was used to conduct the statistical analyses.

\section{Patient and public involvement}

No patients or members of the public were involved in the design of this study.

\section{RESULTS}

\section{Children's flow in Jerash Camp Health Centr}

Figure 1 illustrates the children's flow of anaemia screening and treatment in Jerash Camp Health Centre. The electronic health records did not have any information on laboratory values including $\mathrm{CBC}, \mathrm{MCV}, \mathrm{MCH}$,
RDW or referral to a specialist. Eight hundred children (398 boys and 402 girls) were included in the analysis.

\section{Screening visit}

Table 1 shows the results of the screening visit. Among 800 children, 717 children (353 boys and 364 girls) came to the screening visit, so these 717 children were included in the analysis. The mean $\pm \mathrm{SD}$ age at the screening visit was 12.7 \pm 2.2 months old. All 717 children took the Hb test, and $112(15.6 \%)$ children were diagnosed as moderate to severely anaemic. Their mean \pm SD Hb level was $9.1_{ \pm}$ $0.6 \mathrm{~g} / \mathrm{L}$. Out of 112 children diagnosed as moderate to severely anaemic, 91 children received iron supplements. Additionally, out of 247 children diagnosed as mildly anaemic, 191 children received iron supplements.

\section{First follow-up visit}

Table 2 shows the results of the first follow-up visit. Out of 112 children diagnosed as moderate to severely anaemic at the screening visit, 86 children came to the first follow-up visit and their mean \pm SD age at the visit was $16.0 \pm 3.1$ months old. Their mean \pm SD $\mathrm{Hb}$ level was to $10.1 \pm 1.0$ g/L. And $72(83.7 \%)$ children improved their Hb level, compared with their screening visit. Out of 72 children who improved their $\mathrm{Hb}$ level, 46 children continued to receive iron supplements at the first follow-up visit. On the contrary, out of 14 children who did not improve their $\mathrm{Hb}$ level, 9 children also received iron supplements. Moreover, out of 247 children diagnosed as mildly at the screening visit, 171 children came to the first follow-up visit, respectively. 
Table 1 Results of the electronic health record survey for the screening visit

\section{Children registered in Jerash Camp Health Centre $(n=800)$}

\begin{tabular}{|c|c|c|c|}
\hline Visit to the health centre ( $\mathrm{n}$ & \multicolumn{3}{|c|}{717} \\
\hline Mean age in months (SD) & \multicolumn{3}{|c|}{$12.7(2.2)^{\star}$} \\
\hline Children who received $\mathrm{Hb}$ test $(\mathrm{n})$ & \multicolumn{3}{|c|}{717} \\
\hline \multirow[t]{2}{*}{ Mean $\mathrm{Hb}$ level in $\mathrm{g} / \mathrm{L}(\mathrm{SD})$} & \multicolumn{3}{|c|}{$10.7(0.9)$} \\
\hline & $\begin{array}{l}\text { Non-anaemia } \\
(\mathrm{Hb} \geq 11.0 \mathrm{~g} / \mathrm{L})\end{array}$ & $\begin{array}{c}\text { Mild anaemia } \\
(\mathrm{Hb}=10.0-10.9 \mathrm{~g} / \mathrm{L})\end{array}$ & $\begin{array}{l}\text { Moderate to severe anaemia } \\
\qquad(\mathrm{Hb}<10.0 \mathrm{~g} / \mathrm{L})\end{array}$ \\
\hline Anaemia status at the screening visit, $\mathrm{n}(\%)$ & $358(49.9)$ & $247(34.4)$ & $112(15.6)$ \\
\hline Mean $\mathrm{Hb}$ level in $\mathrm{g} / \mathrm{L}(\mathrm{SD})$ & $11.4(0.3)$ & $10.4(0.2)$ & $9.1(0.6)$ \\
\hline Children who received iron supplements (n) & 19 & 191 & 91 \\
\hline
\end{tabular}

${ }^{*} \mathrm{P}$-value $<0.05$, compared with the recommended age of 12 months by the UNRWA guidelines.

$\mathrm{Hb}$, haemoglobin; UNRWA, United Nations Relief and Works Agency for Palestine Refugees in the Near East.

\section{Second follow-up visit}

Table 3 shows the results of the second follow-up visit. Out of 72 anaemic children who improved their $\mathrm{Hb}$ status at the first follow-up visit, 41 children came to the second follow-up visit. Their mean \pm SD age at the visit was $20.1 \pm$ 4.9 months old, and the mean $\pm \mathrm{SD}$ Hb level was further increased to $10.5 \pm 1.0 \mathrm{~g} / \mathrm{L}$. There were eight $(20.0 \%)$ children who were diagnosed as moderate to severely anaemic at the second follow-up visit, and six children received iron supplements. Moreover, out of 18 children who were diagnosed as mildly anaemic at the second follow-up visit, 17 children received iron supplements.

\section{Third follow-up visit}

Table 4 shows the results of the third follow-up visit. Out of 32 children who were diagnosed as mildly anaemic or non-anaemic at the second follow-up visit, 11 children came to the third follow-up visit, and their mean $\pm \mathrm{SD}$ age at the visit was $21.6 \pm 3.9$ months old. Their mean $\pm \mathrm{SD} \mathrm{Hb}$ level was $10.2 \pm 0.9 \mathrm{~g} / \mathrm{L}$, and three children $(27.2 \%)$ were diagnosed as moderate to severely anaemic at the third follow-up visit. There were six children who received iron supplement at the third follow-up visit.

Overall, we found that children visited the health centre at an age significantly later compared with that recommended by the UNRWA guidelines for the screening, first and second follow-up visits ( $p$-value $<0.05$ ). However, we did not find a significant delay for the third follow-up visit, compared with the age defined in the UNRWA guidelines $(\mathrm{p}=0.64)$.

\section{Adherence to the UNRWA guidelines}

Table 5 shows the patient and doctor adherence to the UNRWA guidelines. For the screening visit, patient adherence was $89.6 \%$ (95\% CI=87.3 to 91.7). Doctor adherence was $100 \%$ for $\mathrm{Hb}$ tests and $81.3 \%$ (95\% CI=72.8 to 88.0 ) for iron supplementation. For the first follow-up visit, patient adherence was decreased to $76.8 \%$ (95\% CI=67.9 to 84.2). Doctor adherence was still $100 \%$ for $\mathrm{Hb}$ tests; however, iron supplementation was decreased to $63.9 \%$ (95\% CI $=51.7$ to 74.9). For the second follow-up visit, patient adherence was further decreased to $56.9 \%$ ( $95 \% \mathrm{CI}=44.7$ to 68.6 ). Doctor adherence to $\mathrm{Hb}$ tests was slightly decreased to $97.6 \%$ (95\% $\mathrm{CI}=87.1$ to 99.9$)$. For the third follow-up visit, patient adherence was further decreased to $34.4 \%$ (95\% CI=18.6 to 53.2). Doctor adherence to $\mathrm{Hb}$ tests was increased back to $100 \%$.

\section{DISCUSSION}

This study illustrates that patient and doctor adherence to treatment guidelines was above $80 \%$ during the screening

Table 2 Results of the electronic health record survey for the first follow-up visit

Children diagnosed as moderate to severely anaemic at the screening visit $(n=112)$

Visits to the health centre $(n)$ 86

Mean age in months (SD) $16.0(3.1)^{\star}$ Children who received $\mathrm{Hb}$ test $(\mathrm{n})$ 86

Mean $\mathrm{Hb}$ level in $\mathrm{g} / \mathrm{L}$ (SD) $10.1(1.0)$

Children with improved $\mathrm{Hb}, \mathrm{n}(\%)$ $72(83.7)$

Improved $\mathrm{Hb}(\mathrm{n}=72)$

46
Not improved $\mathrm{Hb}(\mathrm{n}=14)$

Children who received iron supplements (n)

9

${ }^{*} \mathrm{P}$-value $<0.05$, compared with the recommended age of 13 months by the UNRWA guidelines.

$\mathrm{Hb}$, haemoglobin; UNRWA, United Nations Relief and Works Agency for Palestine Refugees in the Near East. 
Table 3 Results of the electronic health record survey for the second follow-up visit

Children with improved $\mathrm{Hb}$ at the first follow-up visit $(\mathrm{n}=72)$

\begin{tabular}{|c|c|c|c|}
\hline Visit to the health centre (n) & \multicolumn{3}{|c|}{41} \\
\hline Mean age in months (SD) & \multicolumn{3}{|c|}{$20.1(4.9)^{\star}$} \\
\hline Children who received $\mathrm{Hb}$ test $(\mathrm{n})$ & \multicolumn{3}{|c|}{40} \\
\hline \multirow[t]{2}{*}{ Mean $\mathrm{Hb}$ level in g/L (SD) } & \multicolumn{3}{|c|}{$10.5(1.0)$} \\
\hline & $\begin{array}{l}\text { Non-anaemia } \\
(\mathrm{Hb} \geq 10.0 \mathrm{~g} / \mathrm{L})\end{array}$ & $\begin{array}{c}\text { Mild anaemia } \\
(\mathrm{Hb}=10.0-10.9 \mathrm{~g} / \mathrm{L})\end{array}$ & $\begin{array}{c}\text { Moderate to severe } \\
\text { anaemia }(\mathrm{Hb}<10.0 \mathrm{~g} / \mathrm{L})\end{array}$ \\
\hline Anaemia status at the second follow-up visit, $n(\%)$ & $14(35.0)$ & $18(45.0)$ & $8(20.0)$ \\
\hline Mean $\mathrm{Hb}$ level in $\mathrm{g} / \mathrm{L}(\mathrm{SD})$ & $11.5(0.4)$ & $10.4(0.3)$ & $9.0(0.7)$ \\
\hline Children who received iron supplements (n) & 3 & 17 & 6 \\
\hline
\end{tabular}

${ }^{*} \mathrm{P}$-value $<0.05$, compared with the recommended age of 15 months by the UNRWA guidelines.

$\mathrm{Hb}$, haemoglobin; UNRWA, United Nations Relief and Works Agency for Palestine Refugees in the Near East.

visit; however, this progressively decreased at follow-up visits, especially patient adherence at the third follow-up visit of $34.4 \%$. Furthermore, the analysis identifies unnecessary health centre visits and iron supplement prescriptions to mildly anaemic children at the screening and first follow-up visit, and children visited the health centre at an age significantly later compared with that recommended by the UNRWA guidelines for the screening, first and second follow-up visits ( $p$-value $<0.05$ ).

This study shows that there is room to improve patient and doctor adherence to the UNRWA's guidelines. Patient adherence was $89.6 \%$ at the screening visit and decreased to $34.4 \%$ at the third follow-up visit. Also, doctors adherence to iron supplement was $81.3 \%$ at the screening visit and decreased to $63.9 \%$ at the first follow-up visit. This means that approximately $35 \%$ of children at the first follow-up visit and $65 \%$ of children at the third follow-up visit missed opportunities to be diagnosed and treated for anaemia. Additionally, we found that children visited health centres at ages significantly later than recommended in the UNRWA guidelines for the screening, first and second follow-up visits. For example, the mean $\pm \mathrm{SD}$ age of the first follow-up visit was $16.0 \pm 3.1$ months old, although UNRWA guidelines recommend a first follow-up visit at 13 months old. ${ }^{4}$ It is crucial to avoid a delay to health centre visits and treatment for anaemia because anaemia status interferes with normal growth and development, ${ }^{11}$ otherwise, these impairments may become irreversible. ${ }^{4}$ Although patient and doctor adherence to the UNRWA's guidelines should be improved, our study found that the $83.7 \%$ of moderate to severely anaemic children improved their status through iron supplementation. Therefore, $\mathrm{Hb}$ improvement rates via iron supplementation could be increased further if these issues are addressed in the Jerash Camp Health Centre.

Our analysis identified unnecessary health centre visits and iron supplementation in mildly anaemic children. For example, out of 247 children who were diagnosed as mildly anaemic at the screening visit, 191 children received iron supplements and 171 children came to the first follow-up visit. It has been pointed out that UNRWA's health centre tends to be overcrowded, and this may negatively affect the quality of care provided. ${ }^{20}$ Furthermore, UNRWA has faced a financial crisis since 2018 by donors

Table 4 Results of the electronic record survey for the third follow-up visit

Children diagnosed as mildly anaemic or non-anaemia at the second follow-up visit $(n=32)$

Visit to the health centre (n)

11

Mean age in months (SD) $21.6(3.9)^{\star}$

Children who received $\mathrm{Hb}$ test $(\mathrm{n})$ 11

Mean $\mathrm{Hb}$ level in $\mathrm{g} / \mathrm{L}(\mathrm{SD})$ $10.2(0.9)$

\begin{tabular}{lccc} 
& $\begin{array}{c}\text { Non-anaemia } \\
(\mathrm{Hb} \geq 10.0 \mathrm{~g} / \mathrm{L})\end{array}$ & $\begin{array}{c}\text { Mild anaemia } \\
(\mathrm{Hb}=10.0-10.9 \mathrm{~g} / \mathrm{L})\end{array}$ & $\begin{array}{c}\text { Moderate to severe } \\
\mathrm{anaemia}(\mathrm{Hb}<10.0 \mathrm{~g} / \mathrm{L})\end{array}$ \\
\hline Anaemia status at the third follow-up visit & $3(27.3)$ & $5(45.5)$ & $3(27.3)$ \\
Mean $\mathrm{Hb}$ level in $\mathrm{g} / \mathrm{L}(\mathrm{SD})$ & $11.2(0.1)$ & $10.4(0.4)$ & $9.0(0.5)$ \\
Children who received iron supplements $(\mathrm{n})$ & 1 & 4 & 1
\end{tabular}

${ }^{*} \mathrm{P}$-value $=0.64$, compared with the recommended age of 21 month by the UNRWA guidelines.

$\mathrm{Hb}$, haemoglobin; UNRWA, United Nations Relief and Works Agency for Palestine Refugees in the Near East. 
Table 5 Adherence to UNRWA guidelines

Screening visit First follow-up visit Second follow-up visit Third follow-up visit

\begin{tabular}{|c|c|c|c|c|}
\hline \multicolumn{5}{|l|}{ Patient adherence } \\
\hline Health centre visits, \% (95\% Cl) & 89.6 (87.3 to 91.7$)$ & 76.8 (67.9 to 84.2$)$ & 56.9 (44.7 to 68.6$)$ & 34.4 (18.6 to 53.2$)$ \\
\hline \multicolumn{5}{|l|}{ Doctor adherence } \\
\hline Iron supplementation, \% (95\% Cl) & 81.3 (72.8 to 88.0$)$ & 63.9 (51.7 to 74.9$)$ & $\mathrm{N} / \mathrm{A}$ & N/A \\
\hline
\end{tabular}

$\mathrm{Hb}$, haemoglobin; N/A, not applicable; UNRWA, United Nations Relief and Works Agency for Palestine Refugees in the Near East.

ceasing their financial support, and this has negatively affected UNRWA's operation. ${ }^{21}$ Thus, it is very important to avoid unnecessary health centre visits and iron supplementation to utilise the available resources efficiently.

This study found that the burden of childhood anaemia was higher in Jerash Camp Health Centre, compared with non-refugee Jordanian children and Palestinian refugee children in other Jordan's refugee camps. The mean \pm SD $\mathrm{Hb}$ level at the 12-month-old screening in Jerash Camp Health Centre was $10.7_{ \pm} 0.9 \mathrm{~g} / \mathrm{L}$, which was lower than the mean $\pm \mathrm{SD}$ Hb level among non-refugee children aged $12-23$ months old in Jordan of $11.2 \pm 0.16 \mathrm{~g} / \mathrm{L}$ as reported in 2006. ${ }^{6}$ Additionally, we found that half of 12 -month-old children had an $\mathrm{Hb}$ level $<11.0 \mathrm{~g} / \mathrm{L}$ in Jerash Camp Health Centre, which was higher than 12-month-old Palestinian children registered by UNRWA in Jordan of $39.0 \%$ and 6-12 months children in Jerash governorate of $36.9 \%$ in 2019. ${ }^{142}$ Palestinian refugees face poor intake of iron source food due to food insecurity, ${ }^{14}$ and Jerash camp in particular has a higher poverty rate, ${ }^{17}$ which increases the risk of anaemia. UNRWA recommends 6-month exclusive breastfeeding because breast milk contains highly bioavailable iron that helps to restore iron and protect children from infectious diseases. ${ }^{4}$ In 2005, a survey conducted by UNRWA reported that only $25 \%$ of Palestinian children had exclusive breastfeeding up to 4 months in Jordan which was the lowest proportion among five UNRWA regions. ${ }^{23}$ Additionally, a study conducted in Jerash camp reported that mothers could not afford iron rich foods and diverse food to feed their children due to economic hardship. ${ }^{24}$ Some mother gave tea to their infants, which is known as an inhibitor of iron absorption. ${ }^{424}$ This was because mothers faced lactation failure due to their own undernutrition but could not afford to buy formula milk. ${ }^{24}$

This study has important implications for Jerash Camp Health Centre; efforts should be made to improve adherence to the UNRWA guidelines, avoid a delay of health centre visits and decrease unnecessary health centre visits and iron supplementation. Further studies are needed to understand the reason why adherence was decreased at the follow-up visits, whether mothers were informed about when their children should visit the health centre for anaemia screening and treatment and whether doctors correctly understood UNRWA guidelines on when to prescribe iron supplements, especially regarding treatment thresholds between mild anaemia and moderate to severe anaemia.

This study had several limitations. First, our analysis did not consider potential confounding factors such as socioeconomic status, ${ }^{25-27}$ food security, ${ }^{10}$ child anthropometric status ${ }^{27}$ and parent's smoking status ${ }^{26}$ because there was no such information available in electronic health record, which may be associated with patients adherence to UNRWA's guidelines. Second, the analysis of electronic health records included all children born in 2017 and registered in Jerash Camp Health Centre, assuming all of them continued to live in Jerash until 2018 due to lack of data availability. Therefore, the study population $(n=800)$ could be smaller in reality, which would lead to underestimation of adherence to health centre visits for the screening visit. Finally, this study was conducted in Jerash Camp Health Centre only, and so findings may not be readily generalisable to other UNRWA health centres in Jordan or other regions due to the poor economic condition among Palestinian refugees, especially in Jerash camp. Nevertheless, our results provide sufficient stimulus for the need for public health intervention to improve adherence to UNRWA guidelines at follow-up visit and to minimise any unnecessary health centre visits and iron supplementation.

\section{CONCLUSION}

We conducted a retrospective observational study to investigate patient and doctor adherence to UNRWA guidelines in Jerash Camp Health Centre by analysing electronic health records. The patient and doctor adherence was progressively decreased at the follow-up visits especially patient adherence at the third follow-up visit. Children visited health centre at a significantly later age compared with that recommended by the UNRWA guidelines. Also, the analysis identified unnecessary health centre visits and iron supplementation for mildly anaemic children. Further studies are needed to understand why patient and doctor adherence to UNRWA guidelines is lower at follow-up visits, and whether similar patterns are observed in other UNRWA health centres. Furthermore, in order to maximise efficacy of scant UNRWA resources, urgent action is required to improve the adherence to the UNRWA's guidelines and minimise unnecessary health centre visits and iron supplementation. 
Author affiliations

${ }^{1}$ International Affairs and Tropical Medicine, Tokyo Women's Medical University, Tokyo, Japan

${ }^{2}$ Department of Health, Headquarters Amman, United Nations Relief and Works Agency for Palestine Refugees in the Near East Jordan, Amman, Jordan

${ }^{3}$ Department of Public Health, Environments and Society, London School of Hygiene \& Tropical Medicine, London, UK

${ }^{4}$ Center for Human Nutrition, Department of International Health and Sight and Life Global Research Institute, Johns Hopkins Bloomberg School of Public Health, Baltimore, Maryland, USA

${ }^{5}$ Department of Health, Jordan Field Office, United Nations Relief and Works Agency for Palestine Refugees in the Near East Jordan, Amman, Jordan

Acknowledgements The authors appreciate the technical staff at UNRWA Headquarters who cleaned up the data set and provided comments about this manuscript. Additionally, we appreciate all the doctors, nurses, midwives, interpreters and mothers and children who supported in completing the study in Jerash Camp Health Centre.

Contributors YH, NAK, SH, MA and MH designed the study. YH analysed data. YH and NAK interpreted results. YH drafted the paper and NAK, SH, MA, MH, SA, $\mathrm{KAN}, \mathrm{MH}, \mathrm{RH}$ and $\mathrm{AS}$ have seen and approved the final version of the paper. $\mathrm{YH}$ is responsible for the overall content as the guarantor.

Funding The authors have not declared a specific grant for this research from any funding agency in the public, commercial or not-for-profit sectors.

Competing interests None declared.

Patient consent for publication Not required.

Ethics approval This study was conducted according to the guidelines laid down in the Declaration of Helsinki and all procedures involving research study participants were approved by the research review board of UNRWA Headquarters in Amman.

Provenance and peer review Not commissioned; externally peer reviewed.

Data availability statement Data are available upon reasonable request. All data relevant to the study are included in the article or as supplementary information. Some restrictions will apply for the availability of data.

Supplemental material This content has been supplied by the author(s). It has not been vetted by BMJ Publishing Group Limited (BMJ) and may not have been peer-reviewed. Any opinions or recommendations discussed are solely those of the author(s) and are not endorsed by BMJ. BMJ disclaims all liability and responsibility arising from any reliance placed on the content. Where the content includes any translated material, BMJ does not warrant the accuracy and reliability of the translations (including but not limited to local regulations, clinical guidelines, terminology, drug names and drug dosages), and is not responsible for any error and/or omissions arising from translation and adaptation or otherwise.

Open access This is an open access article distributed in accordance with the Creative Commons Attribution Non Commercial (CC BY-NC 4.0) license, which permits others to distribute, remix, adapt, build upon this work non-commercially, and license their derivative works on different terms, provided the original work is properly cited, appropriate credit is given, any changes made indicated, and the use is non-commercial. See: http://creativecommons.org/licenses/by-nc/4.0/.

\section{ORCID iD}

Yuriko Harada http://orcid.org/0000-0002-5128-386X

\section{REFERENCES}

1 Kassebaum NJ, Jasrasaria R, Naghavi M, et al. A systematic analysis of global anemia burden from 1990 to 2010. Blood 2014;123:615-24

2 GBD 2016 Disease and Injury Incidence and Prevalence Collaborators. Global, regional, and national incidence, prevalence, and years lived with disability for 328 diseases and injuries for 195 countries, 1990-2016: a systematic analysis for the global burden of disease study 2016. Lancet 2017;390:1211-59.

3 Kassebaum NJ. The global burden of anemia. Hematol Oncol Clin North Am 2016;30:247-308.

4 United Nations Relief and Works Agency for Palestine Refugees in the Near East. Prevention and treatment guideline for micronutrient deficiencies, 2020.

5 World Health Organization. Global Health Observatory data repository, Anaemia in children $<5$ years. Available: https://apps. who.int/gho/data/node.main.ANEMIACHILDREN?lang=en [Accessed 19 Feb 2022]

6 Kharabsheh SH, Qarqash W, Faqih AM. Iron status in preschool Jordanian children of 12-59 months of age. Jordan Med J 2006;40:4-13.

7 Lozoff B. Iron deficiency and child development. Food Nutr Bull 2007;28:S560-71.

8 Lozoff B, Brittenham GM, Wolf AW, et al. Iron deficiency anemia and iron therapy effects on infant developmental test performance. Pediatrics 1987;79:981-95.

9 Scott SP, Chen-Edinboro LP, Caulfield LE, et al. The impact of anemia on child mortality: an updated review. Nutrients 2014;6:5915-32.

10 Jalambo MO, Karim NA, Naser IA, et al. Prevalence and risk factor analysis of iron deficiency and iron-deficiency anaemia among female adolescents in the Gaza strip, Palestine. Public Health Nutr 2018:21:2793-802.

11 Pineda O, Ashmead HD. Effectiveness of treatment of iron-deficiency anemia in infants and young children with ferrous bis-glycinate chelate. Nutrition 2001:17:381-4.

12 Sundararajan S, Rabe H. Prevention of iron deficiency anemia in infants and toddlers. Pediatr Res 2021;89:63-73.

13 United Nations Relief and Works Agency for Palestine Refugees in the Near East. Health department annual report 2018, 2019.

14 United Nations Relief and Works Agency for Palestine Refugees in the Near East. Health department annual report 2019, 2020.

15 Srour MA, Aqel SS, Srour KM, et al. Prevalence of anemia and iron deficiency among Palestinian pregnant women and its association with pregnancy outcome. Anemia 2018;2018:1-7.

16 Stoltzfus RJ, Dreyfuss ML. Guidelines for the use of iron supplements to prevent and treat iron deficiency anemia. Ilsi Press, 1998.

17 ÅA T, Zhang H. Progress, challenges, diversity: insights into the socio-economic conditions of Palestinian refugees in Jordan. Fafo, 2013.

18 United Nations Relief and Works Agency for Palestibe Refugees in the Near East. Jerash Camp. Available: https://www.unrwa.org/ where-we-work/jordan/jerash-camp [Accessed 15 Jan 2021].

19 Abdo N, Abu Naqera K, Batieha A, et al. Catastrophic health expenditure among ex-Gazan families in Jerash cAMP, Jordan. Public Health 2020;186:101-6.

20 United Nations Relief and Works Agency for Palestibe Refugees in the Near East. Modern and efficient UNRWA health services, 2011.

21 United Nations Relief and Works Agency for Palestibe Refugees in the Near East. UNRWA calls for urgent political and financial support at the Arab League, 2020. Available: https://www.unrwa.org/ newsroom/press-releases/unrwa-calls-urgent-political-and-financialsupport-arab-league [Accessed 16 Jan 2021].

22 Hussein SL, Takruri HR. Assessment of iron status in a sample of infants aged 6-12 months in Jerash Governorate, Jordan. J Heal Med Nurs 2019;59.

23 United Nations Relief and Works Agency for Palestine Refugees in the Near East. Health department annual report 2020, 2000.

24 AbuKishk N, Gilbert H, Seita A, et al. Under-five malnutrition among Palestine refugee children living in camps in Jordan: a mixedmethods study. BMJ Glob Health 2021;6:e005577.

25 Mikki N, Abdul-Rahim HF, Stigum H, et al. Anaemia prevalence and associated sociodemographic and dietary factors among Palestinian adolescents in the West bank. East Mediterr Health $J$ 2011;17:208-17.

26 Sirdah MM, Yaghi A, Yaghi AR. Iron deficiency anemia among kindergarten children living in the marginalized areas of Gaza strip, Palestine. Rev Bras Hematol Hemoter 2014;36:132-8.

27 El Kishawi RR, Soo KL, Abed YA, et al. Anemia among children aged 2-5 years in the Gaza Strip- Palestinian: a cross sectional study. BMC Public Health 2015;15:319. 